\title{
Prison violence in Chilean facilities: A first overview
}

\section{Violencia en las prisiones chilenas: una primera aproximación}

\author{
Recibido el 17 marzo 2016/ publicado el 16 Septiembre 2016
}

\author{
Guillermo E. Sanhueza ${ }^{1}$ \\ Universidad San Sebastián \\ Reuben J. Miller \\ University of Michigan
}

\begin{abstract}
RESUMEN
A pesar de que la violencia carcelaria ha sido estudiada en países desarrollados, existe escasa evidencia empírica del fenómeno en países en desarrollo. Este artículo analiza la violencia al interior de las cárceles chilenas, específicamente para dos de sus más comunes manifestaciones: violencia entre reclusos y aquella que se da desde guardias a internos. Para ello utiliza tanto datos administrativos de Gendarmería de Chile como datos de la Primera Encuesta de Percepción de Calidad de Vida Penitenciaria (Espinoza, Martínez \& Sanhueza, 2014). Los resultados muestran que la violencia entre internos es más probable que ocurra en cárceles con concentraciones más altas de internos jóvenes (IRR=0.786), de alto compromiso (historia) delictual ( $\mathrm{IRR}=1.042$ ) y con mayor población total (IRR=1.0008). Por otro lado, la violencia de guardia a interno es más probable que afecte a hombres $(\mathrm{OR}=3.37)$, de cárceles concesionadas $(\mathrm{OR}=1.64)$; por el contrario, la violencia de guardia a interno es menos probable cuando los internos son visitados más frecuentemente $(\mathrm{OR}=0.77)$, cuando saben cómo llenar reclamos $(\mathrm{OR}=0.75)$ cuando percepción mejor la infraestructura penitenciaria $(\mathrm{OR}=0.68)$. Finalmente, se sugieren implicancias de política pública y nuevas preguntas.
\end{abstract}

\footnotetext{
${ }^{1}$ Autor de correspondencia: Guillermo Sanhueza. Facultad de Ciencias Sociales y Humanidades, Universidad San Sebastián, Bellavista 7, Santiago de Chile 8420524, Chile. guillermo.sanhueza@uss.cl
} 
Palabras clave: Violencia, cárceles, Chile, predictores

\begin{abstract}
Although prison violence has been studied in developed countries, there is little empirical evidence of the phenomenon in developing countries. This article analyzes violence within Chilean facilities, specifically two of its most common manifestations: inmate-inmate violence and guard-inmate. To do so, this study uses both administrative data from Gendarmeria de Chile as well as survey data from the First Survey on Inmates' Perceptions of Prison Life (Espinoza, Martínez \& Sanhueza, 2014). Results show that inmate-inmate violence is more likely to occur in prisons with higher concentrations of young inmates (IRR $=0.786$ ), the proportion of inmates classified with high criminal contagion $(I R R=1.042)$ and a greater total population $(I R R=$ 1.0008). On the other hand, violence from guard to inmates is more likely to affect men $(\mathrm{OR}=3.37)$ and those who live in private prisons $(\mathrm{OR}=1.64)$; on the contrary, having suffered physical mistreatment from guards is less likely when inmates are visited more often $(\mathrm{OR}=0.77)$, when they knew how to fill out grievances $(\mathrm{OR}=0.75)$, and when inmates had a better perception of prison infrastructure $(\mathrm{OR}=0.68)$. Finally, implications for public policy and new questions are suggested.
\end{abstract}

Keywords: Prison, violence, Chile, predictors

\title{
1. Introduction
}

According to many international legal systems, including the Chilean one, when an individual is sent to prison and deprived of liberty, the only right that is suspended while incarcerated is freedom of movement (Alzúa, Rodríguez \& Villa, 2010; Richardson, 1993). Furthermore, in modern, Western societies, imprisonment is imposed on individuals as punishment, not for punishment (Ignatieff, 1978). Nevertheless, a variety of pressures from different sources have made the aspunishment premise less certain and have put consideration for the human rights of the incarcerated at risk (Cavadino et al., 1999; Garland, 2001).

A number of human rights reports have expressed concerns about prisons in Chile not only because of overcrowding (30\% average) and infrastructure problems, but also because of the many ways in which prisons' daily functioning compromises inmates' dignity: many fear for their safety; most lack medical assistance; few have access to productive activities and even fewer to drug treatment; there is an exaggerated 
use of solitary confinement and a significant percentage of inmates have been tortured while in solitary confinement (Instituto Nacional de Derechos Humanos [INDH], 2013; Sanhueza, 2015). These practices violate international standards and threaten inmates' social reintegration.

In this scenario, prison violence emerges as a common, dangerous situation encountered in almost every facility in the country. Indeed, survey data from 2013 (Espinoza, Martínez \& Sanhueza, 2014) shows that a considerable proportion of respondents declared having suffered physical maltreatment by other inmates $(21.1 \%)$ and by uniformed personnel (38.7\%). In addition, inmates identified psychological mistreatment, with $33.7 \%$ of respondents stating that they had suffered psychological mistreatment from other inmates and $44.3 \%$ from guards. Prison violence is problematic because it generates a prison atmosphere that undermines rehabilitative efforts (Liebling, 2004), threatens prison guards and staff (Coyle, 2003), and generates conditions for high recidivism rates (Dammert \& Zúñiga, 2008; Morales, Muñoz, Welsch \& Fábrega, 2012), as almost all inmates, except those who die in prison, will return to the community (Petersilia, 2003).

This article offers a preliminary overview on prison violence (both inmate-oninmate and guard-inmate) in the Chilean case order to analyze its magnitude, variations and main correlates. Despite the fact that prison violence has been studied in other countries, most of such studies come from Western, developed nations that have already invested in prison infrastructure, or implemented high-quality in-prison programming (Andrews, Bonta \& Wormith, 2011), or have a stronger tradition of evidence-based policies and programs (Latessa, 2004), or that have developed a specialized academia that permanently make contributions to the debate (Wacquant, 2001). We believe that studying prisons in a developing country like Chile will contribute to our understanding of the occurrence of prison violence within a society that has come to democracy after a long dictatorship; has progressed economically, yet continued to experience social inequalities; has seen a rise in public insecurity and crime; has experienced a diminished role of state in social life; has done little in terms of the modernization of prison institutions; and that has reduced expectations about prisons as places for rehabilitation.

\section{Literature Review}


Considering the actors who may interact in violent behavior in prisons, the literature has usually divided prison violence into three main categories: inmate-inmate violence; inmate-guard violence; and to a lesser extent, guard-inmate violence. This article focuses on violence between inmates and violence committed by guards against inmates.

\subsection{Inmate-Inmate violence}

Literature on inmate-inmate violence has identified three main theories to explain why it occurs: some have argued that the forced deprivations to which inmates are subjected while incarcerated cause violence (deprivation theory); others have maintained that poor prison management and other organizational factors cause violence inside prisons (administrative-control theory); a third group has reasoned that inmates' background and history prior to incarceration cause in-prison violent behavior (importation theory).

The deprivation model states that prison violence occurs as the result of an adaptive response to the strains of the restricted institutional life experienced by inmates (Clemmer, 1940). Later, in The Society of Captives, Sykes (1958) described in great detail "the pains of imprisonment" as the variety of forced deprivations inmates face in prisons: the loss of freedom; goods and services; heterosexual relations; autonomy; and security. Then, inmates form a subculture in response to such deprivations, with its own argot, inmate code, roles, and values and, thus, inmates' misconduct reflects the adaptive struggle to those losses in permanent opposition to the administration and staff (Paterline \& Petersen, 1999; Sykes \& Messinger, 1960). Some of the variables that have been positively linked to this theory are overcrowding (Farrington \& Nuttall, 1980; Gaes \& McGuire, 1985; Gaes, 1994; Bonta and Gendreau, 1990; Spector, 2010), the security level of the facility (Jayewardene \& Doherty, 1985; McCorkle et al., 1995; Porporino et al., 1987; Steiner, 2009) and inmates' perception of the prison environment (Hochstetler \& De Lisi, 2005; Rocheleau, 2013). A note of caution is that research on crowding and violence might be affected by conceptual and operational inconsistencies across studies and that the definitions of crowding may be culturally-dependent (Wooldredge \& Steiner, 2009). 
On the other hand, the administrative-control theory of inmate-inmate violence assumes that, since prison officials and administrators are to a great extent those who run the prisons, they are determinant actors that influence prison outcomes and inmate behavior, including misconduct and violence (Di Iulio, 1987; Reisig, 2002). Proponents of this model maintain that failures in prison management have been associated with severe forms of inmate violence, including inmate-inmate aggression, inmate homicides, or collective riots (DiIulio, 1987; Reisig, 2002; Snacken, 2005; Sparks, Bottoms \& Way, 1996; Useem \& Kimball, 1989). Some of the indicators that have been employed under the administrative-control model include program availability for inmates and the use of coercive controls (Di Iulio, 1987; Reisig, 1998; Reisig, 2002; Huebner, 2003; Craig, 2004; Steiner, 2009). Under this theory, program availability for inmates would be negatively associated with prison violence - the higher the proportion of prisoners participating in educational programs or vocational training, the less violence there would be among them (McCorkle et al., 1995; Walrath, 2001; Huebner, 2003; Steiner, 2009).

Finally, the importation model maintains that inmates do not arrive to prison in a vacuum in order to be molded by the correctional institution. According to this theory, inmates bring their own values, pre-prison experiences, behavioral patterns and socialization (Irwin \& Cressey, 1962; Jacobs, 1977). As a result, there would be no single "society of captives," but rather, a variety of value systems according to inmates' unique histories and identification with different sub-groups or ethnically-defined gangs. Inmates' age has been considered an influential variable for the importation theory, negatively associated with the occurrence of violence: younger inmates usually show higher levels of violent misconduct (Kuanliang \& Sorensen, 2008; De Lissi et al., 2010; Sorensen \& Cunningham, 2010; Arbach-Lucioni, Martínez-García \& AndrésPueyo, 2012). In addition, being male is positively associated with prison violence (Kuanliang \& Sorensen, 2008; Sorensen \& Cunningham, 2010; Berg \& DeLisi, 2006; Harer \& Stefensmeier, 1996). When the history of prior violence is considered, there is a positive association of previous violence and current violent behavior (De Lisi, Berg, \& Hochstetler, 2004; De Lissi et al., 2010; Arbach-Lucioni, Martinez-García \& AndrésPueyo, 2012; Cunningham \& Sorensen, 2007). 


\subsection{Guard-inmate prison violence}

In his criticism of Goffman's (1961) assertion that prisons were 'total institutions,' Farrington (1994) argues that prisons today are much more exposed to external controls and influences than at the time of Goffman's writing in the sixties. While Farrington's claim might be right in general, there are some exceptions one might be concerned about, particularly in terms of respect for inmates' human rights and the use of (exaggerated) force by guards on inmates.

The Chilean Penitentiary Code permits prison guards to use coercion and force only in cases of extreme necessity, in order to reestablish prison order and to protect inmates themselves from aggressions. Nevertheless, prison violence from guards to inmates within prison contexts is usual in the Chilean context (INDH, 2012; 2013; Sanhueza, 2015).

As Marquart (1986) has pointed out, prison guards use physical coercion and force more often and more violently than what it is supposed to be done. Indeed, he found in a study conducted in Texas that violence was deeply immersed in prison guards' organizational culture, with former officers having 'mentored' younger guards in the use of force and punishing of inmates. Moreover, guards who used force were given preferable postings or promotions.

Since guard-inmate violence is, from a normative point of view, illegal or at least inappropriate behavior, it is difficult to obtain reliable official records on it beyond anecdotal legal complaints or other forms of casuistic evidence. As a result, it has been more difficult to theorize about this phenomenon and to obtain reliable data on the number of abuses, particularly for developing countries.

Nevertheless, and using Goffman versus Farrington's argument on prisons as 'total institutions,' it is reasonable to argue that anything that may allow inmates to be not-so-totally immersed in the prison world would be helpful to 'protect' them from abuses from guards. Thus, visitation patterns, inmates' knowledge about their rights, an adequate infrastructure and program participation are expected to be negatively associated with violence from guards to inmates.

\subsection{Some gaps in the literature on prison violence}


Despite the fact that a body of literature has studied prison violence, this type of research is rare in developing countries (Gendreau, Goggin, \& Law, 1997) and very few studies have been conducted in Latin American prisons, where overcrowding, inherited authoritarian regimes and poor managerial practices make prisons in this region very different from those in developed nations (Dammert \& Zuniga, 2008; Espinoza \& Martinez, 2007; Isla \& Miguez, 2003; INDH, 2012). In addition, most research relies on administrative and official records of misconduct, which usually have limitations for research purposes (such as the lack of control for the researcher over content, the use of administrative definitions that may even vary over time, missing or erroneous data, or outdated information) and only few studies have employed different data sources (Rocheleau, 2013; Hochstetler \& De Lisi, 2005). Finally, few studies have been able to provide a nationwide overview on prison violence that considers two types of violent behavior: inmate-on-inmate and guard-on-inmate. Thus, this study tries to fill part of this research gap by employing two sources of data: administrative information from official records of the Chilean Bureau of Prisons and findings from the First National Survey on Inmates' Perception of Quality of Prison Life, in order to study two manifestations of prison violence: inmate-inmate and guard-inmate.

\section{Methods}

\subsection{Data Sources and Study Sample}

This study presents an overview on prison violence in Chilean prisons regarding inmate-on-inmate as well as guard-on-inmate violence. In order to address these two forms of violent behavior, a combination of both administrative and survey data are employed.

Data for this article were obtained from two sources: (i) administrative records from the Chilean Bureau of Prisons (Gendarmeria, in Spanish) and (ii) the First Survey on Inmates' Perception of Quality of Prison Life (Sanhueza, 2015). Below is a detailed description of the two datasets. 
(i) Administrative Dataset on Violent Events by Prison Facility in 2012 [ADM]

This dataset, ADM, was an Excel file generated by the Statistical Unit of the Gendarmería in Santiago that contains information on the number of recorded violent events by facility in Chile during 2012. This dataset includes official information on violent events for 83 facilities and, thus, is used to analyze inmate-on-inmate violence. Unfortunately, it contains no individual-level information but only facility-level data. This file also contains information on additional variables such as overcrowding, total inmate population, type of prison (public or private), and security level of each prison.

\section{(ii) First Survey on Inmates' Perception of Quality of Prison Life - 2013 [SURVEY]}

SURVEY was a random, nationally representative, face-to-face survey of Chilean adults aged 18 or older living in prison facilities in Chile during the 2013 calendar year. Inmates who completed the questionnaire were randomly selected through a stratified sampling strategy, which was representative at the prison level. It was the first comprehensive assessment on inmates' perception about their conditions of imprisonment in the country. This evaluation work was supported by the Chilean Bureau of Prisons (Gendarmería) - Unit for Protection and Promotion of Human Rights within Gendarmeria in 2013. SURVEY asked 2,093 individuals to answer 42 questions regarding different topics of prison life: i) perception of prison conditions, infrastructure and amenities; ii) perception of physical, psychological and sexual mistreatment by guards or by other inmates; iii) participation in prison programming; iv) stay in solitary confinement (in current prison); and v) priorities for change in this facility, among others. The entire questionnaire took about 30 minutes (on average) to be completed by respondents, who were usually gathered in small chapels, administrative offices, or sport facilities. The overall response rate was $78 \%$ for the entire country (Sanhueza, 2015).

Although SURVEY contained individual-level information, identifiers were later on removed based on ethical reasons. ${ }^{2}$ Indeed, although the SURVEY initially

\footnotetext{
2 Originally, there were identifiers linking inmates' names with individual numeric codes; however, once survey questionnaires were applied, identifiers were removed to protect inmates from possible reprisals or retaliation. Indeed, nationally-representative evaluation had never been conducted before in Chile and, although the Prison Bureau itself (Gendarmería) funded this first study, Gendarmería was most likely not well prepared for dealing with "bad results" on issues like human rights, guards' violence and other
} 
employed a randomized, stratified sampling strategy that identified individuals and gathered information from them, once questionnaires were completed and entered into a database, identifiers were removed and deleted from the dataset in order to i) secure confidentiality and anonymity of the information provided by inmates and ii) to avoid possible adverse effects, reprisals or retaliation effects towards inmates by prison guards or administrators. This decision was taken by the principal investigator of SURVEY.

\subsection{Study variables}

\section{Inmate-on-inmate violence}

Given the broad and multifaceted nature of prison violence (McGuirre, 2008; Wolff, Shi \& Bachman, 2008) and that there is no agreed-upon benchmark for how it should be conceptualized and measured (Jackson \& Brownstein, 2004), it is necessary to provide a definition for "prison violence" to assess its inmate-on-inmate form. We have chosen to examine violent events at the facility level as the dependent variable to examine inmateinmate violence because a facility's level of misconduct reflects degrees of order within a correctional institution (Steiner, 2009) and the inclusion of aggregate, facility-level predictors of violence constitute elements in the overall social structure of a prison that may impact its levels of violence (Bottoms, 1999; Camp, Gaes, Langan \& Saylor, 2003).

Thus, the dependent variable inmate-on-inmate violent events will be understood as the total number of violent events during 2012 according to these criteria:

- The occurrence involves interpersonal, physical violence.

- $\quad$ It involves intentionality (Jackson \& Brownstein, 2004).

malpractices. Acknowledging that these data may have provided critical information about prison life in Chile, it was the decision of the principal investigator to minimize the risk of retaliation against any inmate, for a variety of reasons: the PI did not trust Gendarmeria's zeal for keeping confidentiality and anonymity of inmates (because of previous and naturalized high levels of mistreatment toward inmates), because the dataset was property of Gendarmería and, finally, because of endogamous organizational characteristics of such institution. In sum, balancing the risks of jeopardizing individuals with the importance of scientific inquiry, it was a conscious decision not to identify individuals in the dataset. 
- Refers to a violent event registered as such in official records as a collective fight (riña is the Spanish term for such a situation) ${ }^{3}$. On average, those individuals involved in the fight are identified in $75.5 \%$ of the cases

- According to the Chilean Penitentiary Code, a violent event includes the use of a weapon or an object used as such.

With respect to the Independent Variables, they are the following: ${ }^{4}$

- Occupancy Rate: a number that indicates prison design capacity vs. real occupancy, based on dataset ADM, which was provided by Gendarmería administrative records.

- Mistreatment by guards: composite score that reports average percentage of inmates reporting physical and psychological mistreatment by guards, based on data from SURVEY

- Program participation: Composite score for inmates' perception on access to six possible different types of in-prison programs ${ }^{5}$ in each facility, based on SURVEY.

- Proportion of inmates in solitary confinement: taken from SURVEY, this question asked inmates whether (or not) they had been in solitary confinement in the facility $(0=$ no; $1=$ yes $)$.

- Inmates' average age: based on ADM provided by the Gendarmería's Statistical Unit, these data show the average age of the inmate population by facility at the end of the 2012 year.

- Proportion of inmates classified as having 'high criminal contagion': each inmate is assessed and classified according by the Gendarmería, as a proxy for criminal history. This variable was based on ADM records.

\footnotetext{
${ }^{3}$ Unfortunately, official records kept by the Chilean Bureau of Prisons (Gendarmería de Chile) do not provide any specification in terms of the type of this collective fight ("riña", in Spanish) and the specific characteristics of the event (e.g. simple assault, aggravated assault, attempted murder, murder). This is an important limitation of this dataset that could not be overcome

${ }^{4}$ Although SURVEY was conducted in the first half of 2013 with some of its variables being employed to analyze violent events that took place in 2012, I have made the reasonable assumption (in consultation with prison officers and other scholars in the field) that structural characteristics of prisons in Chile most likely did not change that much between 2012 and 2013. In this regard also, and since this study seeks to offer a first, exploratory account on prison violence, I have relaxed the temporality requirement for establishing causality.

${ }^{5}$ work-for-pay, job skills training, prison school, psycho-social interventions, sport activities, arts
} 
- Total inmate population: An average count of the total inmate population at the facility level is used as a control variable using ADM, which was provided by the Gendarmeria at the end of 2012.

\section{b) Guard-on-inmate violence}

Due to the normative inappropriateness and lack of reliable data on prison guard to inmate violence, one of the only possible ways to collect information on this phenomenon is from self-reports by inmates themselves. Thus, data on guard-inmate violence was gathered through SURVEY instrument.

The dependent variable - Having suffered physical mistreatment by guards- was taken from SURVEY and was a dichotomous variable that asked inmates whether they had suffered any form of physical violence in that particular prison during their stay. $(0=$ no; $1=$ yes $)$.

With respect to the independent variables, they were the following:

- Infrastructure: a composite score (taken from SURVEY) ranging from 0-9 that indicates inmates' perception on food quantity and quality; bathroom conditions; having enough space in their cells or blocks; proper ventilation; adequate temperature; among other indicators. Higher values indicate a better perception on prison conditions. Perception on infrastructure is usually an indicator of deprivation theory.

- How often (inmate) receive visitors: taken from SURVEY, this question asked inmates how often they have received visitors in current facility. Possible values were $1=$ never received visitors; $2=$ once or twice a month; $3=$ every week. The hypothesis says that inmates who receive visitors more often would be less prone to being abused by guards, as (more visited) inmates would be more exposed to external controls.

- Program access: Composite score taken from SURVEY (possible values ranging 0-6) that assessed inmates' perception on their access to six different inprison programs ${ }^{6}$ in their current facility.

\footnotetext{
${ }^{6}$ Paid work, job skills training, prison school, psycho-social interventions, sport activities, arts/cultural programs
} 
- Inmate knows steps to fill out a grievance: taken from SURVEY, this was a dichotomous variable that asked inmates' perception on whether or not they knew how to fill out a grievance in case they had a fair reason to do it $(0=$ no; $1=$ yes).

- Sex: a dichotomist variable to register inmates' sex ( $0=$ woman; $1=$ man $)$. According to the literature, when there is violence from guards against inmates, male inmates tend to be more victimized than women.

- Type of facility: a binary variable that registered whether inmates' prison was a publically or privately-operated facility $(0=$ public; $1=$ private $)$. Private prisons are more modern, security-oriented facilities that offer better conditions for housing the most dangerous inmates. It is expected that there is more violence from guards inside these establishments.

\subsection{Analytical Strategy}

This study included two different questions and two types of analyses to answer each. First of all, inmate-on-inmate violence is analyzed; to do so, descriptive information is presented in terms of violent events and rates of violent events. Thus, descriptive statistics-including means, standard deviations, percentages-are generated to summarize the aggregated characteristics of the number of violent events, the characteristics of the facilities in the sample (since the units of analysis will be prisons, not individuals), and the main characteristics of the independent and control variables.

Then, multivariate models were run: a) both negative binomial regression model and b) logistic regression.

Thus, data for the dependent variable "violent events by facility" show that, among the 83 operating facilities throughout the country, there are reports on violence for 52 of them, with 31 registering no serious violent incidents in 2012. Since violent events were over dispersed, positively skewed, and many facilities reported zero incidents during the observation period, data were analyzed using negative binomial regression, following the approach employed in similar cases in other prison violence studies (e.g. Drury \& DeLisi, 2009; Sorensen \& Cunningham, 2008). The analyses were conducted using STATA 13.0 (StataCorp, 2013). Although negative binomial 
regression model is an appropriate statistical technique for analyzing count data, the coefficients are difficult to interpret. Thus, the results of each model were presented using "Incidence Rate Ratio" (IRR), which refers to the estimated rate of change (increase or decrease) in the number of violent events, for a one-unit increase in the predictor variable, given the other variables being held constant in the model.

To analyze guard-on-inmate violence, descriptive analyses are also conducted on inmates' perceptions of guards' violent behavior and a series of related variables such as inmates' perception on infrastructure, program access, frequency of receiving visitors, inmates' knowledge on how to fill out a formal grievance, among others. Then, a multivariate logistic regression model is run with inmates' responses on whether they had (or not) suffered physical mistreatment by guards as the dependent variable, incorporating a number of co-variables.

\section{Results}

The analyses in this study include two parts. In the first part, administrative data (at the prison level from 2012) provided by the Chilean Prison Bureau were employed to analyze inmate-on-inmate violence; thus, descriptive statistics are presented on the number of violent events by facility, rates of violent events by facility (adjusted by prison population), differences on the rate of violent events by type of facility (privately or publically-operated prisons) and differences by security level. The distribution of some correlates of inmate-on-inmate violence is also presented.

The second part uses data from the First National Survey on Inmates' Perception of Quality of Prison Life conducted in Chilean prisons in 2013 to analyze guard-oninmate violence in 75 (out of 82) prison facilities nationwide. In order to do so, descriptive statistics on self-reported guard-on-inmate violence are presented along with its main correlates: inmates' perception on infrastructure, quality of their relationship with guards, access to rehabilitative programs, visitation patterns, inmate's knowledge on how to fill out a formal grievance, type of prison they inhabit, and sex.

\subsection{Inmate-on-inmate violence}


Descriptive findings

Table 1. Descriptive statistics inmate-on-inmate violence

\begin{tabular}{|l|c|c|c|c|c|c|}
\hline \multicolumn{1}{|c|}{ Variable } & Observations & Mean & Median & $\begin{array}{c}\text { Std. } \\
\text { Deviation }\end{array}$ & Minimum & Maximum \\
\hline $\begin{array}{l}\text { Number of violent } \\
\text { events }\end{array}$ & 75 & 7.9 & 2 & 16.9 & 0 & 91 \\
\hline $\begin{array}{l}\text { Rate of violent events } \\
\text { (per 1,000 } \\
\text { individuals) }\end{array}$ & 75 & 10.97 & 5.16 & 13.32 & 0.00 & 55.55 \\
\hline $\begin{array}{l}\text { Occupancy rate (\%) } \\
\text { Mistreatment by }\end{array}$ & 75 & 125.7 & 121.9 & 54.7 & 32.5 & 346.4 \\
\hline guards (\%)
\end{tabular}

Since SURVEY was conducted in 75 facilities (out of the 83 prisons that were operating at that time), there was a portion of missing data on mistreatment by guards, participation in prison programming, and the proportion of inmates in solitary confinement for 8 prisons $^{7}$. Thus, after excluding missing data, the analytic sample comprised 75 facilities. Table 1 shows the distribution of the variables in the analytic sample:

\footnotetext{
${ }^{7}$ The eight facilities that could not be visited in 2013 were: 1) "CDP Santiago I," which housed about 3,500 in transit, held-for-trial individuals. The reasons for not visiting had to do with logistical problems and the distinctive nature of this private prison; 2) CDP Limache, due to logistical reasons; 3) CDP Quillota, due to a prison fire very close to the date planned for assessment in 2013; 4) "CDP Cochrane" and 5) "CDP Chile Chico," both due to their distant and inaccessible geographic location; 6) "CCP Punta Peuco," due to the fact that it houses former military personnel for crimes against human rights during Pinochet's regime and because it is already known for having better conditions; 7) "CCP Cordillera," closed by an executive decision from the presidency; and 8) "Cárcel de Alta Seguridad," because of the distinctive, nature of the crimes (terrorism) its inmates committed.
} 
Among the 75 prison facilities that were considered in this study, the average number of violent events was 7.9 violent events per prison during 2012, with a broad range of variation between 0 and 91 . Moreover, the standard deviation of 16.9 is related to the fact that there were 27 facilities reporting zero incidents during 2012. In addition, the average occupancy rate of the prison system was 125.7, meaning that there were, on average, around 126 inmates in a space designed for housing only 100 (representing $25.7 \%$ overcrowding); the standard deviation of 54.7 suggests that there is considerable variation between establishments, and the range seems to support this (occupancy rates between $32.5 \%$ and $346.4 \%$ ). The proportion of inmates who reported having been mistreated by prison guards was $36.7 \%$, meaning that, on average, more than one-third of inmates in Chile would have suffered from either physical and/or psychological mistreatment from guards in that facility. The involvement of inmates in prison programming was measured as a composite score (taken from SURVEY) with possible values ranging from 0 to 6 , with zero meaning no participation, and 6 meaning participation in six programs during the length of stay of respondents in a particular prison; the observed mean of 1.63 suggests that one may expect a typical inmate to participate in 1 or 2 programs in every facility. Inmates reporting having been in solitary confinement in the facility constituted about one third of respondents $(32.7 \%)$ according to SURVEY data. The proportion of inmates assessed by the Gendarmería as having "high criminal contagion" was $14.8 \%$ on average, though with important variations between establishments: whereas some facilities housed no individuals with high criminal contagion, this type of inmates composed almost half of the prison population in other facilities $(47.1 \%)$. Finally, in terms of the control variable, the total inmate population had an average value of 570 in the analytic sample, yet important variations in prison size were observed (with a standard deviation of 837 individuals). Indeed, whereas some prisons were operating with as few as 13 inmates, many others housed more than 1,000 individuals $^{8}$. Finally, inmates' mean age was 32.7 years.

In order to adjust for population size, a rate of violent events (per 1,000 individuals) was also generated for each facility. Table 2 (displayed in Appendix A) ordered prisons according to the raw number of violent events they had in 2012. Data

\footnotetext{
8 The Santiago Penitentiary (CDP Santiago Sur) is a particular case as it holds more than 5,000 individuals and is one of the most emblematic, oldest, and largest prison in South America.
} 
indicate that there was a great deal of variation between facilities both in terms of absolute numbers of violent events and rates of events. Not surprisingly, the larger facilities (those housing more than 1,000 inmates) had the highest number of violent events simply because they have more inmates. However, when rates are examined, facilities show more variation and it is possible to visualize "Colina II," CCP Antofagasta and CCP Talca as three of the most violent prisons (with 35.87, 28.14 and 32.85 events per 1,000 inmates respectively). This finding, as simple as it seems, highlights that prison violence is not only a function of prison size (a common belief even among Chilean officers and guards), suggesting a more complex, non-singlevariable story worthy of further examination.

When rates of violent events between inmates are examined by type of prison, no significant associations were found between privately and publically-operated facilities ( $\mathrm{t}=0.376 ; 81 \mathrm{df}$.). Similarly, no significant associations were found between rate of violent events and security score of the prison $(r=0.116 ; p=0.294)$. Table 3 (below) shows the detail of results:

Table 3. Rates of violent incidents by type of facility (publically versus privately managed prisons)

\begin{tabular}{|c|c|c|c|c|c|}
\hline Group & Observations & Mean & Std. Error & Std. Dev. & 95\% confidence interval \\
\hline 0 (public) & 77 & 12.26 & 1.86 & 16.16 & {$[8.59-15.93]$} \\
\hline $\mathbf{1}$ (private) & 6 & 9.76 & 3.47 & 8.50 & {$[0.83-18.69]$} \\
\hline Combined & 83 & 12.08 & 1.72 & 15.71 & {$[8.65-15.51]$} \\
\hline Difference & & 2.49 & 6.69 & & {$[-10.83-15.82]$} \\
\hline
\end{tabular}

In order to provide a more complex analysis of the violent events and their main covariates, we employed negative binomial regression model. ${ }^{9}$ Table 4 shows the results:

\footnotetext{
${ }^{9}$ Data for the dependent variable "violent events by facility" show that, among the 83 operating facilities throughout the country, there are reports of violence for 52 of them, with 31 registering no serious violent incidents in 2012. Since violent events were overdispersed, positively skewed, and many facilities reported zero incidents during the observation period, data were analyzed using negative binomial regression, following the approach employed in similar cases in other studies (e.g. Drury \& DeLisi, 2009; Sorensen \& Cunningham, 2008).
} 
Table 4. Negative binomial regression violent events (inmate-inmate) by facility

\begin{tabular}{|l|c|c|c|c|c|}
\hline \multicolumn{1}{|c|}{ Events } & IRR & Std. Error & $\mathbf{Z}$ & $\mathbf{P}>\mathbf{z}$ & $\begin{array}{c}{[\mathbf{9 5 \%} \text { Confidence }} \\
\text { Interval] }\end{array}$ \\
\hline Occupancy rate & 1.0032 & .0028 & 1.11 & 0.267 & {$[.9975-1.0089]$} \\
\hline $\begin{array}{l}\text { mistreatment by guards } \\
(\text { *100) }\end{array}$ & .9991 & .0090 & -0.10 & 0.923 & {$[.9814-1.0170]$} \\
\hline Program participation & .688 & .1986 & -1.29 & 0.195 & {$[.3907-1.2118]$} \\
\hline $\begin{array}{l}\text { \% in solitary confinement } \\
(\text { (100) }\end{array}$ & 1.015 & .0097 & 1.58 & 0.114 & {$[.9963-1.0344]$} \\
\hline Average Inmate Age & .786 & .0679 & -2.78 & 0.005 & {$[.6641-.9315]$} \\
\hline \% high criminal contagion & 1.042 & .0149 & 2.89 & 0.004 & {$[1.0134-1.0719]$} \\
\hline Total Inmate Population & 10008 & .0002 & 4.20 & 0.000 & {$[1.0004-1.0012]$} \\
\hline Constant & 2203.2 & 6564.82 & 2.58 & 0.010 & {$[6.409-757353.3]$} \\
\hline
\end{tabular}

In terms of the variables included, only three of the indicators were found to be significantly associated to violent events: inmates' average age, proportion of inmates classified with high contagion, and total inmate population. Inmates' average age showed an IRR of $.786(\mathrm{p}=0.005)$, indicating a negative association between inmates' average age and the occurrence of violent events in a prison facility; more precisely, this means that for each incremental rise in inmates' average age at a prison, there is an expected decrease in the rate of violent events by approximately $21.4 \%$, while holding the rest of the variables constant. In other words, a higher concentration of younger inmates is a predictor of the occurrence of violent events.

The second significant variable, the proportion of inmates classified by the Gendarmería with high criminal contagion $(* 100)$, showed a statistically-significant IRR of 1.042 ( $\mathrm{p}=0.004)$, indicating a positive association between these inmates (a proxy for criminal history) and the occurrence of violent events in that particular prison in Chile. More precisely, the IRR value indicates that for each additional one-percent increase in the proportion of inmates with high criminal contagion housed at a certain prison, the rate of violent events it is expected to increase by $4.2 \%$. In other words,

\footnotetext{
${ }^{10}$ In order to facilitate both model calculations and interpretations, three variables (percentage reporting mistreatment by guards, the proportion of inmates reporting mistreatment by guards and the proportion of inmates with "high criminal contagion") were multiplied by 100.
} 
prisons with higher proportions of high criminal contagion inmates would be at more risk of having violent events.

The third significant variable of the model was the control variable, total inmate population, with an IRR of 1.0008 indicating a positive association between the number of prisoners at a facility and the expected occurrence of violent events. In addition, the IRR suggests that for each one-hundred additional inmates a prison houses, the rate of occurrence of violent events can be expected to increase by $8 \%$.

\subsection{Guard-on-inmate violence}

\section{Descriptive findings}

Another manifestation of prison violence is what takes place from guards to inmates. Results from descriptive, univariate statistics are presented in Table 5. Findings reveal, first of all, that about $38.7 \%$ of respondents reported having suffered physical mistreatment by a prison guard in their current facility.

Table 5. Descriptive Statistics guard-on-inmate violence

\begin{tabular}{|l|c|c|c|c|c|}
\hline \multicolumn{1}{|c|}{ Variable } & Observations & Mean & Std. Dev. & Minimum & Maximum \\
\hline $\begin{array}{l}\text { Physical mistreatment by } \\
\text { guards }\end{array}$ & 2044 & $38.7 \%$ & 0.487 & 0 & 1 \\
\hline Infrastructure composite & 1871 & 5.4 & 2.48 & 0 & 9 \\
\hline How often receive visitors & 2033 & 2.29 & 0.77 & 1 & $\begin{array}{c}3 \text { (at least } \\
\text { twice a } \\
\text { month) }\end{array}$ \\
\hline Program access & 1945 & 1.77 & 1.65 & 0 & 6 \\
\hline $\begin{array}{l}\text { Inmate know how to fill out } \\
\text { a grievance }\end{array}$ & 2033 & $29.5 \%$ & 0.456 & 0 & 1 \\
\hline Sex (1=men) & 2093 & $66.7 \%$ & 0.471 & 0 & 1 \\
\hline Type of facility (1= private) & 2093 & $10.8 \%$ & 0.311 & 0 & 1 \\
\hline
\end{tabular}

Among all the the respondents, two thirds (66.7\%) were men, about $10.8 \%$ were housed in privately-operated facilities, they had access to relatively few programs $(1.77$ on average, within a 0-6 range), they ranked prison infrastructure slightly better than the central value (5.4 within a $0-9$ scale), most of them are visited with some regularity, and less than a third $(29.5 \%)$ declared knowing how to fill out a formal grievance or complaint. 
When physical mistreatment by guards is examined by the type of prison, $t$-test analysis (not shown) showed that inmates in publically-operated prisons reported less $(37.5 \%)$ than their counterparts in privately-operated facilities $(48.6 \%)(\mathrm{t}=-3.21 ; 2,042$ df.). At the same time, men were more likely to have reported being mistreated by a guard $(45.0 \%)$ in comparison with women $(25.9 \%)(t=-8.46 ; 2,042 \mathrm{df}$.).

\section{Multivariate analysis}

Results from multivariate, logistic regression for the dependent variable 'reporting having been physically mistreated by guards' are shown in Table 6. Findings reveal all selected variables were significantly associated with the occurrence of guard-inmate violence: being male $(\mathrm{OR}=3.37)$, being in a private prison $(\mathrm{OR}=1.64)$ and having greater access to programs $(\mathrm{OR}=1.20)$ were significant predictors and positively associated with a greater likelihood of having suffered physical violence by prison guards; a better perception on prison infrastructure $(\mathrm{OR}=0.68)$, a higher frequency of visits $(\mathrm{OR}=0.77)$ and knowing the steps to fill out a grievance $(\mathrm{OR}=0.75)$ were negatively associated with the occurrence of physical violence from guards to inmates.

Table 6. Inmate having experienced physical mistreatment by guards - multivariate logistic regression model

Logistic Regression: "Have you suffered any physical violence from a guard in this prison?" $(0=$ no $; 1=y e s)$

\begin{tabular}{|l|c|c|c|c|}
\hline \multicolumn{1}{|c|}{ Physical mistreatment by guards $(\mathbf{1}=\mathbf{y e s})$} & $\begin{array}{c}\text { OR } \\
\mathbf{n = 1 , 7 2 2}\end{array}$ & Std. Error & $\mathbf{Z}$ & $\mathbf{P}>\mathbf{z}$ \\
\hline Infrastructure & 0.682 & 0.017 & -14.92 & 0.000 \\
\hline
\end{tabular}




\begin{tabular}{|l|c|c|c|c|}
\hline How often inmate receives visitors & 0.775 & 0.055 & -3.56 & 0.000 \\
\hline Program participation & 1.200 & 0.041 & 5.21 & 0.000 \\
\hline Inmate knows how to fill out a grievance & 0.750 & 0.096 & -2.24 & 0.025 \\
\hline Sex (male) & 3.373 & 0.428 & 9.57 & 0.000 \\
\hline Private prison & 1.647 & 0.283 & 2.90 & 0.004 \\
\hline Constant & 2.747 & 0.602 & 4.61 & 0.000 \\
\hline
\end{tabular}

\section{Discussion and conclusion}

\subsection{Discussion}

According to many scholars in the field of prisons, prison order is a concept that encompasses legitimacy, mutual respect, and decency; not merely the absence of violence (Sparks \& Bottoms, 1995; Liebling, 2004; Ward, Gannon \& Birgden, 2007). Nevertheless, the absence of violence is a necessary condition for an orderly facility, which in turn is a prerequisite for treatment and rehabilitation (Di Iulio, 1987; Coyle, 2003). Having acknowledged that, this study provides an initial account of prison violence in Chile, especially in light of the scant previous findings in developing nations (Gendreau, Goggin, \& Law, 1997).

Up to the present date, no previous research had systematically examined the topic of prison violence in Chilean prisons, despite some anecdotal evidence or statistical records on the annual number of deaths or injured inmates, none of which incorporates any analysis of covariates. This article examined what variables were the main correlates of violent events in Chilean prisons using administrative data from 75 facilities as well as from a nationwide, survey data, offering the first account for prison violence in Chilean prisons.

Results for inmate-on-inmate violence indicated that inmates' average age remained as a significant predictor of violent events, even after controlling for population size. Inmates' age and violence were found to be negatively associated, which was consistent with previous studies on prison violence in developed countries, as well as with the daily experience of officers, guards, and my own visits to dozens of Chilean prisons in 2013. In informal interviews and conversations with the author, prison officers and guards commented that they had observed changes in inmate 
demographics in recent years in Chile, with higher concentrations of younger inmates and higher rates of violence. In addition, and in line with the study's expectations, the proportion of inmates identified by the Gendarmería as highly contaminated in criminal behavior, used here as a proxy variable for criminal history, was also found to be positively associated with the occurrence of violent events. Using Drury and De Lisi's (2010) expression, findings supported the idea that "the past is prologue" for current violence, at least for the dependent variable here considered.

However, since collected data did not include individual-level variables, one should interpret these preliminary, exploratory findings with caution, avoiding the ecological fallacy; besides, the mechanisms by which higher concentrations of younger inmates are related to more violent events are unclear from this study and further research is needed.

Finally, and also in line with our expectations, the total inmate population was positively associated with the occurrence of violent events, and its influence resisted the statistical influence of many other variables. One explanation for this positive association could be related to the competition for scarce prison resources that occurs as the inmate population increases. A complementary explanation for this positive association could be that as the prison population increases, prison life becomes more anonymous and inmates may feel that their needs are not met by an increasingly moredistant administration, not just in terms of food or clothes but also in terms of "attention" and opportunities to be recognized as an individual human being.

On the other hand, contrary to our expectations, neither program participation nor the proportion of inmates in solitary confinement were significant predictors of inmate-on-inmate violence in the Full Model. It is possible that the non-significant coefficient for program participation may have had to do with the composite score employed for developing such a measure; indeed, this study created a composite score for program participation by combining responses on six programs of very different nature, including sports, job skills, access to an in-prison paid job, arts, psycho-social intervention, and access to in-prison school. These programs serve different purposes, and it is possible that participation in all of them may not necessarily tackle a criminogenic need (Andrews, Bonta \& Wormith, 2011). The six programs may all have the common characteristic of occupying time, but there is a difference between 
individuals "using" time versus those "filling in" time (Alzúa, Rodrigues \& Villa, 2008), not to mention the importance of consistency in prison programs, which is a prerequisite for success (Andrews, Bonta \& Wormith, 2011).

In terms of guard-on-inmate violence, and in line with our expectations and the literature we reviewed, male inmates were more prone to have suffered physical violence by prison personnel than their female counterparts. Part of this finding may be related to socialization and gender processes and stereotypes, which are present (and perhaps amplified) among inmates, where violence sometimes plays a central role in the definition of masculine identity inside prisons.

In addition, being in a private prison increased the chances of suffering physical violence. Empirical evidence in this study does not clarify the reason for this significant association. One possibility is that, given the selective assignment of inmates sent to private prisons (usually inmates requiring higher levels of security), prison guards try to maintain control by exercising greater violence against inmates. Alternatively, it may be that everyday life in private prisons, which are more modern and segregated, somehow breaks the "prison code" (Irwin and Cressey, 1962), which has been an important, social element in Chilean prisons, thereby creating a greater sense of loneliness and rebellion.

A greater frequency of visits was a factor that reduced the chances of suffering violence by officials; this may occur because inmates who are visited more often may retain a greater connection to the outside world, which, in turn, might help them endure the pains of imprisonment (Sykes, 1958). Thus, they may assume a more docile and less confrontational attitude toward guards for fear of losing visitation privileges.

Findings also showed a negative association between inmates knowing procedures to fill out formal grievances and the chances of having suffered physical violence by guards. This finding is consistent with literature highlighting the importance of information flows inside prison walls (Slade, 2015) and with human-rights initiatives taking place in Chilean facilities recently in order to make inmates more aware of their rights and responsibilities.

A finding that appeared contrary to our expectations was the positive association between perceiving greater access to programs and the greater chances of suffering physical violence by officials. One explanation may be that, by participating in more instances outside the cells, prisoners are also differentially more "exposed" to the 
control and supervision of guards that those who participate less or do not; complementary, it is possible that prison officers and guards may want to discipline those who they perceive as more embedded in reintegration processes through greater participation in programs.

Supposedly, guard-on-inmate physical mistreatment is something that should not take place inside prisons. In Chile, custodians are state agents that need to abide by the law in terms of not hurting individuals under their control. Certainly, they are authorized to use force, but no more than necessary to, for example, separate a fight or to protect another officer in very special circumstances. Guard-on-inmate violence should be better understood and measures should be taken in order to regulate and train guards in using it legitimately.

\subsection{Limitations}

Despite its potential contribution to the literature on prison violence, particularly for the Chilean case and possibly for other Latin American countries, this exploratory account has some limitations that must be taken into account when considering the findings.

First of all, in terms of the definition of violence used by this study, "violence among inmates' was circumscribed here to 'violent events' recorded as such by each prison facility, so prison violence may include different manifestations than simply physical, interpersonal fights among inmates; moreover, because Gendarmería's records did not detail the specific characteristics of such fights, it was not possible to distinguish whether events involved simple assault, aggravated assault, attempted murder or murder.

A second limitation of this study has to do with the fact that it employed aggregated, facility-level variables with no individual-level information available for either of the two datasets here employed. Inmates' individual characteristics are important to understanding prison violence (Drury \& De Lisi, 2010; Kuanliang \& Sorensen, 2008) and there is, certainly, some risk of misinterpreting findings by just applying the ecological fallacy. Nevertheless, due to the possibility of identifying inmates' individual responses and the risk of reprisals or future retaliation against them data from SURVEY were anonymized and the identifiers, removed. 
A third limitation had to do with the use of secondary, administrative data, which implies the possibility of some inconsistency while recording violent events across different prisons. Administrative records usually have not been thought to inform social research and, consequently, they have not considered scientific criteria for their formulation, nor have they passed through control mechanisms.

\subsection{Strengths}

Many variables for this study were taken from the SURVEY that was conducted in 2013. Despite the fact that research in prisons are not easy to conduct and that response rates varies enormously among studies, the high response rate (78\%, fairly uncommon for prison studies), the random-stratified sampling strategy, the no-guard-present-whilesurveying policy we employed, and the high number of prisons visited (75 out of 83) allow us to feel confident that the data taken from that study are valid and reliable. In addition, this study was conducted in cooperation with the Chilean Bureau of Prisons, in an innovative partnership that may initiate a long-term cooperation towards the modernization of the prison system in Chile. Methodologically, this study employed two sources of data (both administrative records and survey data) to study two different forms of violence: inmate-inmate and guard-inmate, despite their methodological challenges. In addition, this study was the first systematic study of prison violence in Chilean prisons, which may stimulate the development of new studies in the region that, hopefully, may help prison administrators and policymakers in designing and implementing programs to reduce prison violence.

\subsection{Policy recommendations}

Since this study is a first overview on prison violence, policy recommendations should be cautious and divided according to the type of violence (inmate-on-inmate or guardinmate). For example, to reduce inmate-inmate violence and since our findings seem to lend preliminary support for the importation model of prison violence, facilities housing higher concentrations of younger inmates and/or higher concentrations of prisoners classified as having "high criminal contagion" should be monitored more cautiously 
than others, as a higher number of violent events is expected to occur. One concrete policy might be to improve classification and segregation systems, avoiding higher concentrations of younger and/or "high criminal contagion" inmates to be housed together in the same prison blocks. However, this will require additional investment on prison infrastructure and personnel's training. In addition, in order to reduce guardinmate violence, some initiatives may be taken in terms of improving prison guards' training, especially in terms of inmates' human rights, conflict management and/or tools on an appropriate and effective use of force. Additional measures may include efforts to improve prisons' accountability and standards, through informative campaigns for inmates to become more aware of their rights and internal procedures to fill out grievances or to communicate with prison authorities.

\subsection{Future Research}

The men and women incarcerated in Latin American prisons are disadvantaged individuals whose initial handicap will not improve after incarceration. At the same time, imprisoned populations in Chile remain relatively invisible to the rest of society, as do the potential social causes associated with higher concentrations of poorer individuals incarcerated. Future research might make more visible part of these gaps in terms of educational levels, neighborhood disadvantage, poverty and so forth in order to generate empirical evidence that may help to reduce "social violence" associated with disadvantage and incarceration. Ethnographic-oriented studies could also contribute to disentangling the mechanisms by which violence takes place in prisons. Finally, further longitudinal studies may help to understand the effects that introducing changes to the prison system has on violence.

\section{Acknowledgments}

We are grateful for the logistic support provided by Gendarmería de Chile and for the research infrastructure provided by the University of Michigan, School of Social Work

\section{Funding}

This article was possible to the support from FONDECYT Iniciación \#11150840 


\section{References}

Alzúa, M. L., Rodríguez, C., \& Villa, E. (2010). The quality of life in prisons: Do educational programs reduce in-prison conflicts? In The Economics of Crime: Lessons For and From Latin America (pp. 239-264). University of Chicago Press.

Andrews, D., Bonta, J \& Wormith, J. (2011). The Risk-Need-Responsivity (RNR) Model. Does Adding the Good Lives Model Contribute to Effective Crime Prevention? Criminal Justice and Behavior, 38, 735-755

Arbach-Lucioni, K., Martinez-García, M., \& Andrés-Pueyo, A. (2012). Risk Factors for Violent Behavior in Prison Inmates A Cross-Cultural Contribution. Criminal Justice and Behavior, 39(9), 1219-1239.

Berg, M. T., \& DeLisi, M. (2006). The correctional melting pot: Race, ethnicity, citizenship, and prison violence. Journal of Criminal Justice, 34(6), 631-642.

Bonta, J., \& Gendreau, P. (1990). Reexamining the cruel and unusual punishment of prison life. Law and Human Behavior, 14(4), 347-372.

Bottoms, A. E. (1999). Interpersonal Violence and Social Order in Prisons. Crime and Justice, 26, 205-281.

Briggs, C. S., Sundt, J. L., \& Castellano, T. C. (2003). Effect of Supermaximum Security Prisons on Aggregate Levels of Institutional Violence. Criminology, 41(4), 1341-1376.

Byrne, J. M., \& Hummer, D. (2007). Myths and realities of prison violence: A review of the evidence. Victims and Offenders, 2(1), 77-90.

Camp, S. D., Gaes, G. G., Langan, N. P., \& Saylor, W. G. (2003). The influence of prisons on inmate misconduct: A multilevel investigation. Justice Quarterly, 20(3), 501-533.

Cavadino, M., Crow, I., \& Dignan, J. (1999). Criminal Justice 2000: Strategies for a New Century. London: Waterside Press.

Clemmer, D. (1940). The Prison Community. New Braunfels: Christopher Publishing House.

Couso, J. A. (2008). The Limits of Law for Emancipation (in the South): Dealing with Prisoners' Rights in Post-authoritarian Chile. Griffith Law Review, 16(2), 330. 
Coyle, A. (2003). Prison reform efforts around the world: The role of prison administrators. Pace Law Review, 24(2), 77-80.

Craig, S. C. (2004). Rehabilitation Versus Control: An Organizational Theory of Prison Management . Prison Journal, 84(4), 92S-114S.

Cunningham, M. D., \& Sorensen, J. R. (2007). Predictive factors for violent misconduct in close custody. The Prison Journal, 87(2), 241-253.

Dammert, L., \& Zuñiga, L. (2008). La cárcel: Problemas y Desafíos para las Américas. Santiago: FLACSO.

DeLisi, M., Berg, M., \& Hochstetler, A. (2004). Gang members, career criminals and prison violence: Further specification of the importation model of inmate behavior. Criminal Justice Studies, 17(4), 369-383.

DeLisi, M., Drury, A. J., Kosloski, A. E., Caudill, J. W., Conis, P. J., Anderson, C. A., \& Beaver, K. M. (2010). The cycle of violence behind bars: Traumatization and institutional misconduct among juvenile delinquents in confinement. Youth Violence and Juvenile Justice, 8(2), 107-121.

Dilluio, J. J. (1987). Governing Prisons. A comparative study of correctional managment. New York: The Free Press.

Drury, A. J., \& DeLisi, M. (2010). The past is prologue: Prior adjustment to prison and institutional misconduct . The Prison Journal, 90(3), 331-352.

Ekland-Olson, S. (1986). Crowding, Social Control, and Prison Violence-Evidence From the Post-Ruiz Years in Texas. Law and Society Review, 14(5), 389-421.

Espinoza, O., Martínez, F. \& Sanhueza, G. (2014). El Sistema penitenciario y su Impacto en los Derechos Humanos de las Personas Privadas de Libertad. En: Informe sobre Derechos Humanos en Chile 2014. Santiago: Ediciones Universidad Diego Portales

Farrington, D., \& Nuttall, C. (1980). Prison Size, Overcrowding, Prison Violence, and Recidivism. Journal of Criminal Justice, 8(4), 221-231.

Gaes, G. G. (1994). Prison crowding research reexamined. The Prison Journal, 74(3), 329-363.

Gaes, G. G., \& McGuire, W. J. (1985). Prison Violence: The Contribution of Crowding Versus Other Determinants of Prison Assault Rates. Journal of Research in Crime and Delinquency, 22(1), 45-65. 
Garland, D. (2001). Mass Imprisonment: Social Causes and Consequences. London: Sage Publications.

Gendreau, P., Goggin, C., \& Law, M. (1997). Predicting Prison Misconducts. Criminal Justice and Behavior, 24(4), 414-431.

Goffman, E. (1968). Asylums: Essays on the Social Situation of Mental Patients and Other Inmates. Doubleday Anchor, New York.

Harer, M. D., \& Steffensmeier, D. J. (1996). Race and Prison Violence. Criminology, 34(3), 323-355.

Hochstetler, A., \& DeLisi, M. (2005). Importation, deprivation, and varieties of serving time: An integrated-lifestyle-exposure model of prison offending. Journal of Criminal Justice, 33(3), 257-266.

Huebner, B. M. (2003). Administrative Determinants of Inmate Violence: A Multilevel Analysis. Journal of Criminal Justice, 31(2), 107-117.

Ignatieff, M. (1978). A Just Measure of Pain: The Penitentiary in the Industrial Revolution, 1750-1850. New York: Pantheon Books.

Instituto Nacional de Derechos Humanos [INDH]. (2013). Informe Anual Situación de los Derechos Humanos en Chile 2013. Santiago.

Irwin, J., \& Cressey, D. R. (1962). Thieves, Convicts and the Inmate Culture. Social Problems, 10(2), 142-155.

Jackson, S., \& Brownstein, H. (2004). The need for a theory of violence. In M. A. Zahn, H. H. Brownstein, \& S. L. Jackson, Violence: from theory to research (pp. 251-261). LexisNexis Anderson Publishing: Newark.

Jacobs, J. B. (1977). Statesville. The Penitentiary in Mass Society. Chicago: The University of Chicago Press.

Jan, L. J. (1980). Overcrowding and Inmate Behavior Some Preliminary Findings. Criminal Justice and Behavior, 7(3), 293-301.

Jayewardene, C. H., \& Doherty, P. (1995). Individual Violence in Canadian Penitentiaries. Canadian Journal of Criminology, 27(4), 429-439.

Kuanliang, A., \& Sorensen, J. (2008). Predictors of self-reported prison misconduct. Criminal Justice Studies, 21(1), 27-35.

Latessa, E. (2004). The Challenge of Change: Correctional Programs and EvidenceBased Practices. Criminology \& Public Policy, 3 (4), 547-560. 
Liebling, A. (2004). Prisons and their moral performances: A study of values, quality and prison life. Oxford: Oxford University Press.

McCorkle, R. C., Miethe, T. D., \& Drass, K. A. (1995). The roots of prison violence: A test of the deprivation, management, and "not-so-that" institution models. Crime \& Delinquency, 41(3), 317-331.

McGuire, J. (2008). A Review of Effective Interventions for Reducing Aggression and Violence. Philosophical Transactions of the Royal Society B: Biological Sciences, 363(1503), 2577-2597.

Morales, A., Muñoz, N., Welsch, G. \& Fábrega, J. (2012). La Reincidencia en el Sistema Penitenciario Chileno. Santiago: Fundación Paz Ciudadana.

Paterline, B. A., \& Petersen, D. M. (1999). Structural and Social Psychological Determinants of Prisonization. Journal of Criminal Justice, 27(5), 427-441.

Petersilia, J. (2003). When prisoners come home: Parole and prisoner reentry. New York: Oxford University Press.

Porporino, F. J., Doherty, P. D., \& Sawatsky, T. (1987). Characteristics of homicide victims and victimizations in prisons: A Canadian historical perspective. International journal of offender therapy and comparative criminology, 31(2), 125-136.

Reisig, M. D. (1998). Rates of Disorder in Higher-Custody State Prisons: A Comparative Analysis of Managerial Practices. Crime \& Delinquency, 44(2), 229-244.

Reisig, M. D. (2002). Administrative Control and Inmate Homicide. Homicide Studies, 6(1), 84-103.

Richardson, G. (1993). Law, Process and Custody: Prisoners and patients. London: Weidenfeld \& Nicholson.

Rocheleau, A. M. (2013). An Empirical Exploration of the "Pains of Imprisonment" and the Level of Prison Misconduct and Violence. Criminal Justice Review, $38(3), 354-374$.

Sanhueza, G. (2015). Diseño e Implementación de la Primera Encuesta de Calidad de Vida Penitenciaria: Propuestas y Desafíos para el sistema penitenciario chileno. Economía y Política 2(1), 5-32.

Snacken, S. (2005). Forms of violence and regimes in prison: report of research in Belgian Prisons. In A. Liebling, The Effects of Imprisonment (pp. 36-339). Portland: Willan Publishing. 
Sorensen, J., \& Cunningham, M. D. (2010). Conviction offense and prison violence: A comparative study of murderers and other offenders. Crime \& Delinquency, 56(1), 103-125.

Sparks, J. R., \& Bottoms, A. E. (1995). Legitimacy and order in prisons. British Journal of Sociology, 46(1), 45-62.

Sparks, R., Bottoms, A. E., \& Hay, W. (1996). Prison and the Problem of Order. Oxford: Oxford University Press.

Spector, D. (2010). Everything Revolves around Overcrowding: The state of California's Prisons. Federal Sentencing Reporter, 22(3), 194-199.

StataCorp. 2013. Stata Statistical Software: Release 13. College Station, TX: StataCorp LP.

Steiner, B. (2009). Assessing Static and Dynamic Influences on Inmate Violence Levels. Crime \& Delinquency, 55(1), 134-161.

Sykes, G. M. (1958). The society of captives: A study of a maximum security prison. Princeton: Princeton University Press.

Sykes, G. M., \& Messinger, S. L. (1960). The Inmate Social System. In R. A. Cloward, Theoretical Studies in Social Organization of Prison (pp. 5-19). New York: Social Science Research Council.

Useem, B., \& Kimball, P. (1989). States of Siege: US Prison Riots, 1971-1986. . New York: Oxford University Press on Demand.

Walrath, C. (2001). Evaluation of an Inmate-Run Alternatives to Violence Project: The Impact of Inmate-to Inmate Intervention. Journal of Interpersonal Violence, 16(7), 697-711.

Ward, T., Gannon, T. A., \& Birgden, A. (2007). Human Rights and the Treatment of Sex Offenders. Sexual Abuse: A Journal of Research and Treatment, 19(3), 195-216.

Wolff, N., Shi, J., \& Bachman, R. (2008). Measuring Victimization Inside Prisons: Questioning the Questions. Journal of Interpersonal Violence, 23(10), 13431362.

Wooldredge, J. D., \& Steiner, B. (2009). Comparing Methods for Examining Relationships Between Prison Crowding and Inmate Violence. Justice Quarterly, 26(4), 795-826. 
Guillermo Sahueza is assistant professor at Universidad San Sebastián, Escuela de Trabajo Social

Reuben J. Miller is assistant professor at University of Michigan, School of Social Work 


\section{Appendices}

Appendix A: Rates on violent incidents in Chilean prisons, 2012

Table 2. Rates on violent incidents in Chilean prisons, 2012

\begin{tabular}{|c|c|c|c|c|}
\hline Prison Name & $\begin{array}{c}\text { Inmate } \\
\text { Population }\end{array}$ & $\begin{array}{l}\text { Violent events } \\
\text { per } 1,000\end{array}$ & $\begin{array}{c}\text { Number of violent } \\
\text { events }\end{array}$ & $\begin{array}{c}\text { Privately } \\
\text { operated } \\
\text { prison? }\end{array}$ \\
\hline $\begin{array}{l}\text { CDP SANTIAGO } \\
\text { SUR }\end{array}$ & 5240 & 17.37 & 91 & \\
\hline CCP COLINA II & 2258 & 35.87 & 81 & \\
\hline CP VALPARAISO & 2868 & 23.01 & 66 & \\
\hline ССР ВIO ВIO & 1273 & 24.35 & 31 & \\
\hline $\begin{array}{l}\text { CCP } \\
\text { ANTOFAGASTA }\end{array}$ & 1066 & 28.14 & 30 & \\
\hline COLINA I & 1745 & 16.62 & 29 & \\
\hline CCP TALCA & 822 & 32.85 & 27 & \\
\hline CCP CURICO & 577 & 45.06 & 26 & \\
\hline CP LA SERENA & 1944 & 12.86 & 25 & yes \\
\hline CCP CAUQUENES & 462 & 47.62 & 22 & \\
\hline CDP PUENTE ALTO & 1362 & 14.68 & 20 & \\
\hline CDP QUILLOTA & 529 & 28.36 & 15 & \\
\hline CP PUERTO MONTT & 1247 & 12.03 & 15 & Yes \\
\hline CCP SAN ANTONIO & 455 & 26.37 & 12 & \\
\hline CCP TEMUCO & 698 & 17.19 & 12 & \\
\hline CDP LIMACHE & 291 & 30.93 & 9 & \\
\hline UEAS & 204 & 44.12 & 9 & \\
\hline CCP LINARES & 345 & 23.19 & 8 & \\
\hline CP ALTO HOSPICIO & 1913 & 4.18 & 8 & Yes \\
\hline SANTIAGO 1 & 3757 & 2.13 & 8 & Yes \\
\hline CCP SANTA CRUZ & 251 & 27.89 & 7 & \\
\hline CP RANCAGUA & 1941 & 3.61 & 7 & Yes \\
\hline CDP MULCHEN & 126 & 47.62 & 6 & \\
\hline CP CONCEPCION & 1447 & 4.15 & 6 & Yes \\
\hline CDP CALAMA & 549 & 9.11 & 5 & \\
\hline CDP TALAGANTE & 452 & 11.06 & 5 & \\
\hline CP ARICA & 1961 & 2.55 & 5 & \\
\hline CDP ARAUCO & 100 & 40.00 & 4 & \\
\hline CDP TOCOPILLA & 295 & 13.56 & 4 & \\
\hline CP PUNTA ARENAS & 210 & 19.05 & 4 & \\
\hline CP VALDIVIA & 1310 & 3.05 & 4 & Yes \\
\hline CCP COPIAPO & 695 & 4.32 & 3 & \\
\hline
\end{tabular}

Revista Española de Investigación Criminológica

Artículo 1, Número 14 (2016)

WwW.criminologia.net

ISSN: 1696-9219 


\begin{tabular}{|c|c|c|c|c|}
\hline CCP CORONEL & 100 & 30.00 & 3 & \\
\hline CCP RENGO & 177 & 16.95 & 3 & \\
\hline CCP IQUIQUE & 315 & 6.35 & 2 & \\
\hline CCP SAN FELIPE & 316 & 6.33 & 2 & \\
\hline CCP VICTORIA & 121 & 16.53 & 2 & \\
\hline CDP ANGOL & 373 & 5.36 & 2 & \\
\hline CDP LEBU & 137 & 14.60 & 2 & \\
\hline CDP PITRUFQUEN & 101 & 19.80 & 2 & \\
\hline CDP VALLENAR & 295 & 6.78 & 2 & \\
\hline CDP VILLARRICA & 261 & 7.66 & 2 & \\
\hline CPF TALCA & 822 & 2.43 & 2 & \\
\hline CCP LOS ANDES & 430 & 2.33 & 1 & \\
\hline CCP OSORNO & 386 & 2.59 & 1 & \\
\hline CDP ILLAPEL & 113 & 8.85 & 1 & \\
\hline CDP LOS ANGELES & 19 & 52.63 & 1 & \\
\hline CDP PETORCA & 13 & 76.92 & 1 & \\
\hline CDP PEUMO & 221 & 4.52 & 1 & \\
\hline $\begin{array}{l}\text { CDP PUERTO } \\
\text { AYSEN }\end{array}$ & 74 & 13.51 & 1 & \\
\hline CDP TALTAL & 83 & 12.05 & 1 & \\
\hline CPF TEMUCO & 42 & 23.81 & 1 & \\
\hline CCP CHAÑARAL & 207 & 0.00 & 0 & \\
\hline CCP CHILLAN & 628 & 0.00 & 0 & \\
\hline CCP CORDILLERA & & & 0 & \\
\hline CCP COYHAIQUE & 112 & 0.00 & 0 & \\
\hline CCP LAUTARO & 109 & 0.00 & 0 & \\
\hline $\begin{array}{l}\text { CCP NUEVA } \\
\text { IMPERIAL }\end{array}$ & 190 & 0.00 & 0 & \\
\hline CCP PUNTA PEUCO & & & 0 & \\
\hline CCP RIO BUENO & 86 & 0.00 & 0 & \\
\hline CDP ANCUD & 79 & 0.00 & 0 & \\
\hline CDP CASABLANCA & 95 & 0.00 & 0 & \\
\hline CDP CASTRO & 130 & 0.00 & 0 & \\
\hline CDP CHANCO & 57 & 0.00 & 0 & \\
\hline CDP CHILE CHICO & & & 0 & \\
\hline CDP COCHRANE & & & 0 & \\
\hline CDP COMBARBALA & 13 & 0.00 & 0 & \\
\hline CDP CURACAUTIN & 66 & 0.00 & 0 & \\
\hline CDP LA LIGUA & 69 & 0.00 & 0 & \\
\hline CDP OVALLE & 331 & 0.00 & 0 & \\
\hline CDP PORVENIR & 24 & 0.00 & 0 & \\
\hline $\begin{array}{l}\text { CDP POZO } \\
\text { ALMONTE }\end{array}$ & 125 & 0.00 & 0 & \\
\hline
\end{tabular}

Revista Española de Investigación Criminológica

Artículo 1, Número 14 (2016)

WwW.criminologia.net

ISSN: 1696-9219 


\begin{tabular}{|l|c|c|c|c|}
\hline CDP PTO. NATALES & 26 & 0.00 & 0 & \\
\hline CDP QUIRIHUE & 95 & 0.00 & 0 & \\
\hline CDP SAN CARLOS & 93 & 0.00 & 0 & \\
\hline CDP SAN MIGUEL & 316 & 0.00 & 0 & \\
\hline CDP TRAIGUEN & 103 & 0.00 & 0 & \\
\hline CDP VICUNA & 16 & 0.00 & 0 & \\
\hline CDP YUMBEL & 124 & 0.00 & 0 & \\
\hline CDP YUNGAY & 115 & 0.00 & 0 & \\
\hline CPF SANTIAGO & 1318 & 0.00 & 0 & \\
\hline CPF & 150 & 0.00 & 0.00 & \\
\hline CNTOFAGASTA & 104 & & 0 & \\
\hline
\end{tabular}

Revista Española de Investigación Criminológica

Artículo 1, Número 14 (2016)

WwW.criminologia.net

ISSN: 1696-9219 


\section{Appendix B: 2013 Survey Questionnaire}

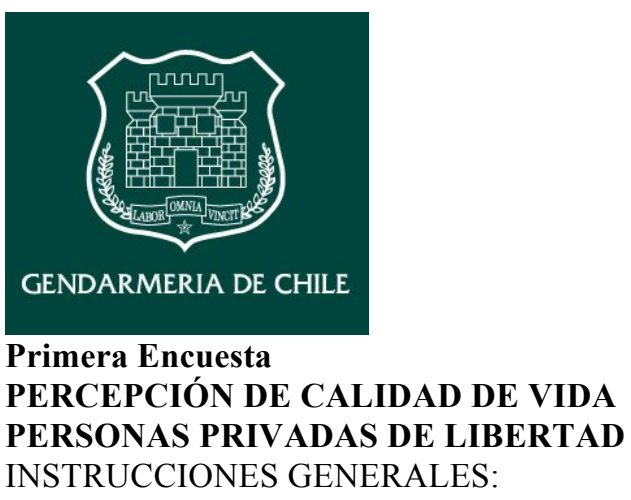

Mi nombre es [nombre del encuestador]. Colaboro con la Unidad de Derechos Humanos de Gendarmería y estamos realizando una encuesta sobre la situación de las personas privadas de libertad en las cárceles de todo Chile. Esta encuesta es anónima y confidencial -nadie sabrá qué fue lo que usted contestó-y tomaría alrededor unos 40 minutos. Las preguntas tienen que ver con la vida al interior de esta unidad, la relación con los funcionarios y con otros internos. Participar en esta encuesta no tendría beneficios directos para usted; ni en cuanto beneficios intra-penitenciarios ni dinero. Usted está en libertad de no contestar cualquier pregunta que no quiera contestar 0 , inclusive, usted podría detener la entrevista en cualquier momento por cualquier razón.Sin embargo, su opinión es muy importante porque nos ayudará a entender mejor la situación en las cárceles chilenas y para mejorar la vida carcelaria. Le pedimos que por favor nos ayude y conteste esta encuesta de la forma más honesta posible

Las preguntas 1-10 tienen que ver con las condiciones de vida en esta cárcel. Le pedimos que responda SI o NO de la manera más honesta posible. Por lo general en esta unidad penal usted...

\begin{tabular}{|c|c|c|c|}
\hline \multirow[t]{6}{*}{$\begin{array}{l}\text { Condiciones } \\
\text { Penitenciarias }\end{array}$} & $(1)$ & $\begin{array}{l}\text { ¿Recibe porciones de comida suficientes } \\
\text { durante el día? }\end{array}$ & $\begin{array}{l}\text { [1] } \mathrm{SÍ} \\
{[0] \mathrm{NO}}\end{array}$ \\
\hline & $(2)$ & $\begin{array}{l}\text { ¿Recibe su comida en buen estado y } \\
\text { caliente? }\end{array}$ & $\begin{array}{l}\text { [1] } \mathrm{SÍ} \\
{[0] \mathrm{NO}}\end{array}$ \\
\hline & (3) & $\begin{array}{l}\text { En el contexto de lo que es una unidad penal } \\
\text { ¿tiene espacio suficiente en su módulo } \\
\text { (colectivo)? }\end{array}$ & $\begin{array}{l}\text { [1] SÍ } \\
\text { [0] } \mathrm{NO}\end{array}$ \\
\hline & (4) & ¿Tiene acceso a una ducha diaria? & $\begin{array}{l}{[1] \mathrm{SÍ}} \\
{[0] \mathrm{NO}}\end{array}$ \\
\hline & $(5)$ & $\begin{array}{l}\text { ¿Cuenta con un baño (wáter) en buenas } \\
\text { condiciones? }\end{array}$ & $\begin{array}{l}\text { [1] } \mathrm{SÍ} \\
{[0] \mathrm{NO}}\end{array}$ \\
\hline & (6) & ¿Duerme en un lugar limpio ( $\sin$ insectos o & $\begin{array}{l}\text { [1] } \mathrm{SÍ} \\
{[0] \mathrm{NO}}\end{array}$ \\
\hline
\end{tabular}




\begin{tabular}{|c|c|c|}
\hline & $\begin{array}{l}\text { (7) ¿Tiene una temperatura adecuada en su } \\
\text { celda (módulo galería colectivo)? }\end{array}$ & $\begin{array}{l}\text { [1] SÍ } \\
\text { [0] NO }\end{array}$ \\
\hline & $\begin{array}{l}\text { (8) ¿Tiene ventilación adecuada en su celda } \\
\text { (módulo galería colectivo)? }\end{array}$ & $\begin{array}{l}{[1] \text { SÍ }} \\
\text { [0] NO }\end{array}$ \\
\hline & $\begin{array}{l}\text { (9) ¿Tiene luz suficiente en su celda (módulo } \\
\text { galería colectivo)? }\end{array}$ & $\begin{array}{l}\text { [1] Sí } \\
\text { [0] NO }\end{array}$ \\
\hline & $\begin{array}{l}\text { (10) Considerando todos los aspectos ¿cómo son } \\
\text { las condiciones de vida en esta unidad? }\end{array}$ & $\begin{array}{l}\text { [1] Buenas } \\
\text { [2] Regulares } \\
\text { [3] Malas }\end{array}$ \\
\hline \multicolumn{3}{|c|}{$\begin{array}{l}\text { Las preguntas 11-16 tienen que ver con su percepción de seguridad al interior de esta cárcel. } \\
\text { Algunas preguntas son delicadas y le pedimos que conteste SI o NO de la manera más honesta } \\
\text { posible. En esta unidad usted... }\end{array}$} \\
\hline \multirow[t]{6}{*}{$\begin{array}{l}\text { Seguridad } \\
\text { Personal }\end{array}$} & $\begin{array}{l}\text { (11) ¿Ha sufrido maltrato físico (golpes patadas) } \\
\text { por parte de otros internos? }\end{array}$ & $\begin{array}{l}\text { [1] SÍ } \\
\text { [0] NO }\end{array}$ \\
\hline & $\begin{array}{l}\text { (12) ¿Ha sufrido maltrato físico (golpes "pago al } \\
\text { contado") por parte de funcionarios? }\end{array}$ & $\begin{array}{l}\text { [1] Sí } \\
{[0] \text { NO }}\end{array}$ \\
\hline & $\begin{array}{l}\text { (13) ¿Ha sufrido maltrato psicológico (insultos } \\
\text { maltrato verbal) por parte de otros internos? }\end{array}$ & $\begin{array}{l}\text { [1] SÍ } \\
\text { [0] NO }\end{array}$ \\
\hline & $\begin{array}{l}\text { (14) ¿Ha sufrido maltrato psicológico (insultos } \\
\text { maltrato verbal) por parte de funcionarios? }\end{array}$ & $\begin{array}{l}\text { [1] Sí } \\
\text { [0] NO }\end{array}$ \\
\hline & $\begin{array}{l}\text { (15) ¿Ha sufrido abuso sexual por parte de otro } \\
\text { interno? (cualquier contacto sexual sin } \\
\text { consentimiento) }\end{array}$ & $\begin{array}{l}\text { [1] SÍ } \\
\text { [0] NO }\end{array}$ \\
\hline & $\begin{array}{l}\text { (16) ¿Ha sufrido algún tipo de abuso sexual por } \\
\text { parte de algún funcionario? }\end{array}$ & $\begin{array}{l}{[1] \text { SÍ }} \\
{[0] \text { NO }}\end{array}$ \\
\hline \multicolumn{3}{|c|}{ Las preguntas 17-19 tienen que ver con la relación con funcionarios en esta unidad. } \\
\hline \multirow[t]{3}{*}{$\begin{array}{l}\text { Trato y relaciones } \\
\text { interpersonales }\end{array}$} & $\begin{array}{l}\text { (17) En esta unidad penal ¿cómo es el trato diario } \\
\text { que recibe de los funcionarios? }\end{array}$ & $\begin{array}{l}\text { [1] Bueno } \\
\text { [2] Regular } \\
\text { [3] Malo }\end{array}$ \\
\hline & $\begin{array}{l}\text { (18) En esta unidad penal ¿cómo es su relación } \\
\text { con los funcionarios? }\end{array}$ & $\begin{array}{l}\text { [1] Buena } \\
\text { [2] Regular } \\
\text { [3] Mala }\end{array}$ \\
\hline & (19) ¿Siente que esta unidad hay un trato más o & [1] Sí \\
\hline
\end{tabular}

Revista Española de Investigación Criminológica

Artículo 1, Número 14 (2016)

www.criminologia.net

ISSN: 1696-9219 
menos justo hacia los internos?

[2] Más o menos

[3] No

Las preguntas 20-21 tienen que ver con la atención médica y de enfermería aquí.

\begin{tabular}{|l|l|l|l}
$\begin{array}{l}\text { Situación de Salud } \\
\text { y Acceso a } \\
\text { servicios } \\
\text { Sanitarios }\end{array}$ & $\begin{array}{l}\text { En esta unidad ies fácil o difícil acceder a } \\
\text { atención médica o de enfermería si lo } \\
\text { necesita? }\end{array}$ & $\begin{array}{l}\text { [1] Fácil atención } \\
\text { [2] Más o Menos }\end{array}$ \\
\cline { 2 - 3 } & $\begin{array}{l}\text { [3] Difícil atención } \\
\text { médica o de enfermería? }\end{array}$ & $\begin{array}{l}\text { [1] Buena atención } \\
\text { [2] Más o Menos }\end{array}$ \\
[3] Mala atención
\end{tabular}

Las preguntas 22-24 tienen que ver con las visitas que usted recibe en la cárcel. Le pedimos que responda de la manera más honesta posible.

\begin{tabular}{|c|c|c|}
\hline \multirow[t]{3}{*}{$\begin{array}{l}\text { Visitas y } \\
\text { con el entacto } \\
\text { exterior }\end{array}$} & $\begin{array}{l}\text { (22) En esta cárcel ¿cuántas veces ha recibido } \\
\text { visitas durante el último mes? }\end{array}$ & $\begin{array}{l}\text { [1] No he recibido } \\
\text { visitas } \\
\text { [2] Una o dos veces al } \\
\text { mes } \\
\text { [3] Todas/casi todas las } \\
\text { semanas }\end{array}$ \\
\hline & $\begin{array}{l}\text { (23) En esta unidad ¿cómo tratan en general a las } \\
\text { visitas? }\end{array}$ & $\begin{array}{l}\text { [1] Mal } \\
\text { [2] Regular } \\
\text { [3] Bien }\end{array}$ \\
\hline & $\begin{array}{l}\text { (24) ¿Quién(es) lo han visitado? (puede marcar más } \\
\text { de una alternativa) }\end{array}$ & $\begin{array}{l}\text { [1] Esposa/Pareja } \\
\text { [2] Hijo(a) } \\
\text { [3] Madre/Padre } \\
\text { [4] Otro familiar o } \\
\text { amigo }\end{array}$ \\
\hline
\end{tabular}

Las preguntas 25-26 tienen que ver con solicitudes y reclamos hacia Gendarmería. Le pedimos que responda SI o NO de la manera más honesta posible.

\begin{tabular}{|l|l|l|l}
\hline $\begin{array}{l}\text { Solicitudes } \\
\text { Reclamos }\end{array}$ & $\mathbf{y}$ & $\begin{array}{c}(25) \text { ¿Conoce los pasos a seguir para hacer algún un } \\
\text { reclamo? }\end{array}$ & {$[1]$ Sí } \\
{$[0]$} & NO
\end{tabular}




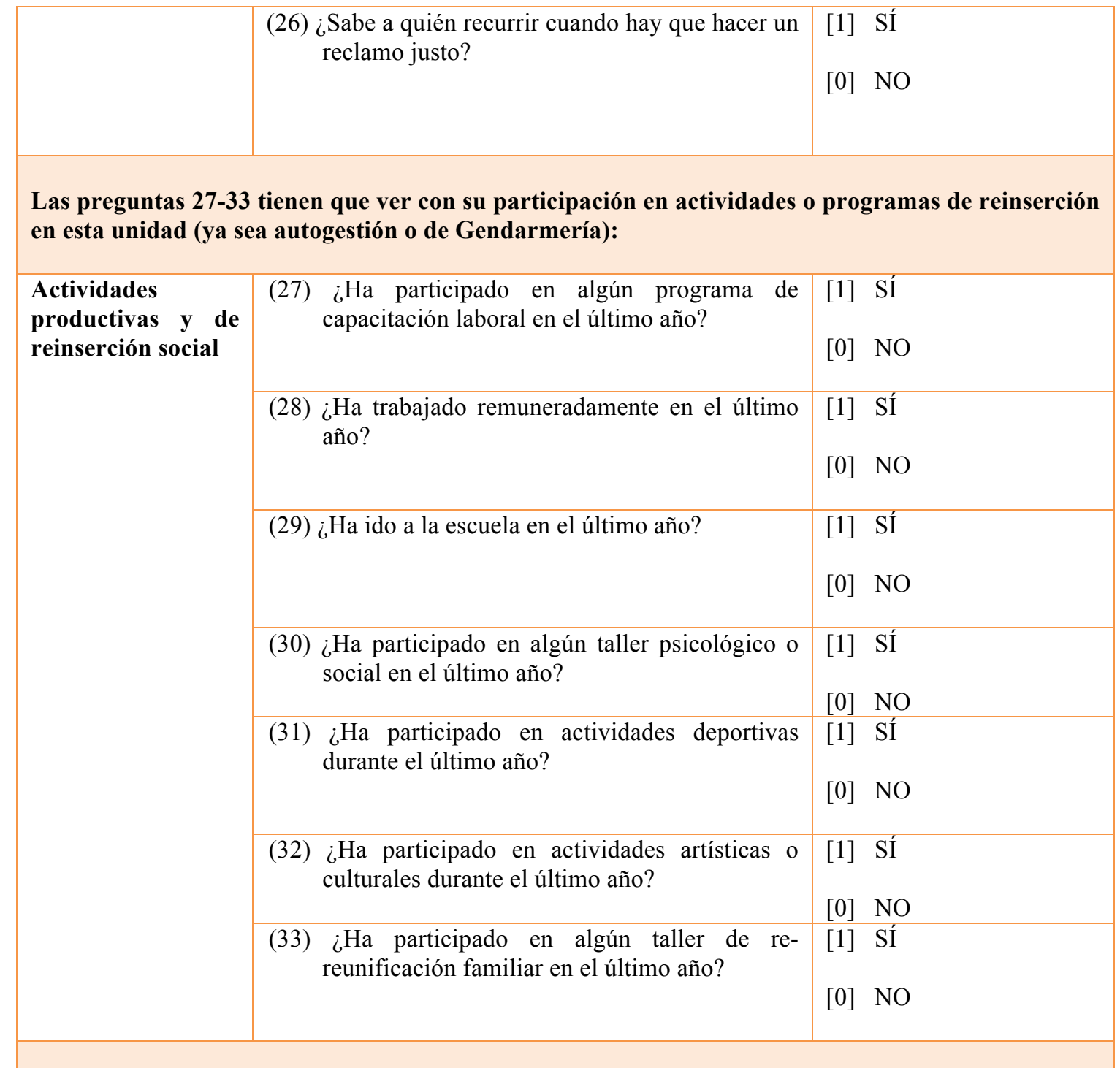

Las preguntas 34-35 tienen que ver con estadía en celda de castigo. Le pedimos que conteste SI o NO de la manera más honesta posible.
Celdas de castigo
(34) ¿Ha estado en celda de castigo en esta unidad?
[1] SÍ
[0] $\mathrm{NO}$
(35) ¿Ha sido torturado (golpeado o maltratado en extremo o de manera cruel) mientras estaba en el castigo?
[1] SÍ
[0] NO

Las preguntas 36-37 tienen que ver con los procedimientos de allanamiento. Le pedimos que conteste SI o NO de la forma más honesta posible.

\begin{tabular}{|l|l|l|l|}
\hline Allanamientos & $\begin{array}{l}\text { (36) Durante los allanamientos en esta unidad ¿le } \\
\text { han dañado o robado pertenencias personales? }\end{array}$ & $\begin{array}{l}{[1] \text { SÍ }} \\
{[0] \text { NO }}\end{array}$ \\
\cline { 2 - 3 } & (37) ¿Ha sido torturado (golpeado o maltratado en $[1]$ SÍ
\end{tabular}




\begin{tabular}{|c|c|c|}
\hline & $\begin{array}{l}\text { extremo o de manera cruel) mientras estaba en } \\
\text { el castigo? }\end{array}$ & [0] $\mathrm{NO}$ \\
\hline \multicolumn{3}{|c|}{$\begin{array}{l}\text { Las preguntas 38-40 tienen que ver con los traslados a otras unidades. Le pedimos que conteste SI } \\
\text { o NO de la forma más honesta posible. }\end{array}$} \\
\hline \multirow[t]{3}{*}{$\begin{array}{l}\text { Traslados a Otras } \\
\text { Unidades }\end{array}$} & (38) ¿Es usted de esta misma región? & $\begin{array}{l}\text { [1] SÍ } \\
{[0] \mathrm{NO}}\end{array}$ \\
\hline & $\begin{array}{l}\text { (39) Mientras ha estado en esta unidad iha } \\
\text { solicitado traslado a otra unidad penal? }\end{array}$ & $\begin{array}{l}\text { [1] } \mathrm{SÍ} \\
{[0] \mathrm{NO}}\end{array}$ \\
\hline & $\begin{array}{l}\text { (40) ¿Ha sido bien recibida su solicitud de } \\
\text { traslado? }\end{array}$ & $\begin{array}{l}\text { [1] } \mathrm{SÍ} \\
{[0] \mathrm{NO}}\end{array}$ \\
\hline \multicolumn{3}{|c|}{$\begin{array}{l}\text { Las pregunta } 41 \text { tienen que ver con el derecho a votar. Le pedimos que conteste SI o NO de la } \\
\text { forma más honesta posible. }\end{array}$} \\
\hline $\begin{array}{l}\text { Votación en } \\
\text { Elecciones }\end{array}$ & $\begin{array}{l}\text { (41) Si usted pudiera votar en las próximas } \\
\text { elecciones ¿estaría dispuesto a hacerlo? }\end{array}$ & $\begin{array}{l}\text { [1] SÍ } \\
{[0] \mathrm{NO}}\end{array}$ \\
\hline \multicolumn{3}{|c|}{$\begin{array}{l}\text { La pregunta } 42 \text { tiene que ver con las cosas más urgentes de cambiar en esta cárcel. Sabemos que } \\
\text { usted quisiera cambiar muchas cosas pero le pedimos que marque las TRES más importantes para } \\
\text { usted. }\end{array}$} \\
\hline $\begin{array}{l}\text { Principales } \\
\text { Cambios que usted } \\
\text { haría en esta } \\
\text { cárcel }\end{array}$ & $\begin{array}{l}\text { (42) ¿Cuáles con los } 3 \text { aspectos más urgentes de } \\
\text { cambiar en esta unidad penal (puede marcar } \\
\text { entre una y tres alternativas)? }\end{array}$ & $\begin{array}{l}\text { [A] Mejor trato a las } \\
\text { visitas } \\
\text { [B] Mejor trato a los } \\
\text { internos }\end{array}$ \\
\hline
\end{tabular}

